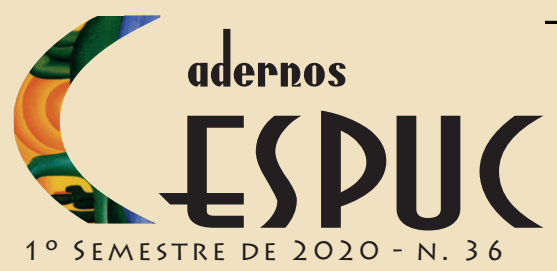

\title{
ANTROPOFAGIA EM ACORDES DISSONANTES: UMA POSSIVVEL DIGESTÃO DE UM ANTROPÓFAGO INDIGESTO
}

\author{
Roberta Maria Ferreira Alves*
}

\begin{abstract}
Resumo
"Decifra-me ou devoro-te". Desafio lançado pela Esfinge de Tebas, um monstro exótico metade leão, metade mulher que lançava charadas aos viajantes e comia aqueles que não fossem capazes de decifrar o enigma proposto. $\mathrm{Na}$ tragédia grega de Sófocles, o conhecimento era a salvação; como uma forma de punição, a criatura apenas devorava aqueles que não se apresentassem capazes de resolver o que lhes era proposto. Em um contexto distanciado temporal e espacialmente, encontramos os rituais antropofágicos dos índios Tupinambá, representantes do exotismo do novo mundo, que, de maneira inversa, devoravam apenas seus inimigos que tivessem qualidades positivas. Era, pois, uma forma de valorização do outro. No início do século XX, Oswald de Andrade afirma em seu manifesto antropofágico que só a "antropofagia nos une", propondo nitidamente que deveríamos "deglutir" o legado cultural europeu e "digeri-lo" sob a forma de uma arte tipicamente brasileira. Este trabalho pretende analisar as reverberações dessa forma antropofágica em um outro momento da produção artística: o movimento cultural Tropicalismo. Para tanto trabalharemos com a letra da canção ícone do movimento tropicalista - a composição do baiano Caetano Veloso - partindo do princípio dissonante de que essa canção da música popular brasileira, com semelhanças e diferenças, funciona como uma reverberação antropofágica na construção do que entendemos como identidade brasileira.
\end{abstract}

Palavras-chave: Antropofagia. Identidade. Reverberações. Tropicalismo. Cultura Brasileira.

\section{ANTHROPOPHAGY IN DISSONANT AGREEMENTS: A POSSIBLE INDIGESTUOUS ANTHROPOPHAGUS DIGESTION}

\begin{abstract}
"Decipher me or I will devour you." Challenge launched by the Sphinx of Thebes, an exotic monster half lion, half woman who launched enigmas to travelers and ate those who were unable to decipher the proposed enigma. In the Greek Sophocles's tragedy, the knowledge was salvation; as a punishment form, the creature only devoured those who did not appear capable of resolving what was proposed to them. In a context that is temporally and spatially distant, we find the anthropophagic Tupinambá Indians' rituals the representatives of the exoticism of the new world, which, conversely, devoured only their enemies who had positive qualities. It was, therefore, a way of valuing the other. At the beginning of the 20th century, Oswald de Andrade affirms in his anthropophagic manifest that only "anthropophagy unites us", clearly proposing that we should "swallow" the European cultural legacy and "digest" it in the form of a typical Brazilian art intends to analyze the reverberations of this anthropophagic shape in another moment of artistic production: the cultural movement "Tropicalismo". To do so, we will work with the lyrics of the icon song of the tropicalist movement - Caetano Veloso's composition - based on the dissonant principle that this Brazilian popular music song, with similarities and differences, works as an anthropophagic reverberation in the construction of what we understand as Brazilian identity.
\end{abstract}

Keywords: Anthropophagy. Identity. Reverberations. Tropicalismo. Brazilian Culture.

Recebido em 21/05/2020 // Aceito em 13/07/2020

"Universidade Federal dos Vales do Jequitinhonha e Mucuri (UFVJM). Doutora em Literaturas de Língua Portuguesa pela Pontifícia Universidade Católica de Minas Gerais - PUCMinas . Professora do Bacharelado de Ciência e Tecnologia.

ORCID: https://orcid.org/0000-0003-3187-7553. 
Ingerir, absorver, engolir, empanturrar-se, digerir, devorar, deglutir, boiar, consumir, lambiscar, experimentar, lamber, ingerir, ingurgitar, experienciar, manducar, nutrir-se, papar, petiscar, provar, saborear, tragar, verbos sinônimos para o verbo comer, que, como verbo transitivo, sempre requer um objeto, e que, como outros, só produz sentidos em contextos enunciativos.

Importante lembrar que, dentro de uma variedade de significados para o verbo comer, podemos simplesmente entendê-lo a partir de seu significado mais comum, o ato de tomar algo como alimento, a ingestão básica de um alimento sólido. Suprindo a necessidade natural de alimentar-se para sobreviver. Em um sentido figurado, podemos percebê-lo como dissipar, consumir, causar certo desgaste de um material ou superfície, corroer. Existe também a possibilidade de ser algo que cause comichão, ou até mesmo o fato de sermos trapaceados em um jogo, como na expressão "comer mosca". Há ainda de uma forma bem popular de um recurso linguístico, uma forma bem mineira de ser, quando omitimos algumas letras ao pronunciarmos um vocábulo. Assim, a palavra certinho se transforma em "certim", pois, literalmente, "comemos", em nossa oralidade, a terminação do vocábulo.

De todos esses significados do verbo comer, gostaríamos de nos fixar apenas em alguns. Nossa atenção se volta, primeiramente, para quando tal vocábulo está ligado ao ato de sobrevivência, importância pura e simplesmente alimentar. Reservando uma atenção particular à relação existente entre dado cultural e dado alimentar/"natural", levaremos em consideração o fato de que estamos refletindo sobre um alimento muito particular: o próprio dado cultural. Trata-se da produção do homem, cultura, que se torna, dentro de uma estrutura altamente ritualizada, alimento para a produção de outro homem, o qual, por sua vez, vive na perspectiva, altamente significativa para sua cultura, de se tornar, um dia, ele mesmo alimento para os outros.

Pelo fato de reconhecer a importância do dado cultural no que diz respeito à alimentação do homem, a Antropologia se apresenta como perspectiva imprescindível de análise. Por outro lado, ela constituirá o esboço de um estudo crítico sobre sua própria caraterística de compreensão/digestão da alteridade cultural. Caso nos detivéssemos apenas na antropofagia ritual "sagrada", teríamos nosso ponto de vista voltado para um estudo histórico-religioso, o que não é alvo de nosso interesse no momento.

Para começarmos a desenvolver o termo antropofagia, no sentido que o adotaremos em nossas reflexões, partiremos de uma análise do sentido desse termo no Novo Mundo nos séculos XVI e XVII. São muito conhecidas no imaginário social ocidental histórias de selvagens e insaciáveis comedores de carne humana que habitavam as margens mais extremas da sociedade ocidental. Até o fim do século XV o termo "antropófago" manteve inalterado seu significado clássico. Mas, ao encerrar-se o século XV, a extraordinária descoberta de novos selvagens do Novo Mundo amplia, de maneira aparentemente ilimitada, tanto as possibilidades das descobertas geográficas, quanto a natureza a identitária dos habitantes das novas, imensas fronteiras da cultura. 
Além do mais, essa descoberta torna evidente o fato de que, ao redor da prática antropofágica americana, começa a se tecer um sistema de traduções - tanto da alteridade americana em face da Europa, quanto das novas e inquietantes alteridades culturais europeias - que contribui para que as considerações sobre a colonização da América se tornem, por exemplo, um pretexto para os propagandistas da fé católica porem a nu os horrores da Reforma. De fato, a Europa torna, na esteira da Antiguidade clássica, a falar de si através da imagem dos gentios bárbaros que teimam em comer carne humana.

É de grande importância pensar sobre essa degradação da imagem do outro universalizada por uma consciência europeia em detrimento das demais civilizações. Sempre houve uma idealização exacerbada do herói europeu colonizador em contraponto com uma completa selvageria e barbárie dos indígenas colonizados. Dessa forma a antropofagia ritualística tem seu sentido substituído, em nome da filosofia e da ciência, em um esquema determinista que restabelece o ato colocando de lado o seu anterior significado e o costume à sujeição natural. O canibal é apenas mais um ser que come o outro, um predador sem consciência e sem ideal, que, no caso de extrema escassez de víveres, vira seu apetite contra seus semelhantes.

Praticada por várias tribos nas Américas, a cerimônia antropofágica tupinambá se tornou um "sucesso" mundial com os relatos do alemão Hans Staden, que viveu dois anos com praticantes da antropofagia, sendo interessante salientar que quase foi devorado por eles. Esse final trágico não aconteceu, pois a "iguaria" não atendeu a uma especificação básica; o alemão foi considerado covarde. À época do "descobrimento", os tupinambá habitavam todo o litoral, desde o Pará até São Paulo. E, nas muitas guerras que disputavam, transformavam em "iguarias" os índios, os mamelucos e os brancos que capturavam. Para os nativos, ser comido era uma honra reservada a guerreiros, mas, aos olhos dos colonizadores europeus, nada poderia ser tão diabólico. Em suma o que para os europeus não passava de um simples ato de canibalismo no qual um homem come o outro como forma de alimentação /sobrevivência, para os Tupinambá era um ritual de manutenção de valores valiosos.

Segundo o cronista alemão, a antropofagia praticada pelos Tupinambá, não passava de uma atitude movida pelo ódio: "Eles fazem assim não para satisfazer a própria fome, mas por hostilidade, por grande ódio [...]. (STADEN, 1974: II, cap. XXV). Na concepção do religioso e entomólogo francês, Claude d'Abeville, o costume nada mais era do que um simples ato diabólico de vingança e ódio contra inimigos:

Não é prazer propriamente que as leva [as mulheres] a comer tais petiscos, nem o apetite sensual, pois de muitos ouvi dizer que não raro a vomitam depois de comer, por não ser o seu estômago capaz de digerir a carne humana; fazem-no só para vingar a morte de seus antepassados e saciar o ódio invencível e diabólico que votam a seus inimigos. (d'Abbeville, 1975: 233)

Assim, podemos perceber que o comportamento antropofágico dos índios era avaliado apenas como um ato efetuado em represália à morte dos próprios parentes, e o que se destacava era que a vingança de sangue era o único motivo de tais atitudes. 
$\mathrm{Na}$ leitura da prática antropofágica proposta naquela época, por distintos grupos, parece destacar-se, de fato, uma apropriação, tanto fisiológica quanto cultural, sem que isso represente uma contradição. Fica claro que essa apropriação cultural é diferentemente representada dependendo de se tratar de endocanibalismo ${ }^{2}$ (em alguns casos das culturas indígenas americanas) ou de exocanibalismo ${ }^{3}$ (como no caso Tupinambá). Nessa sequência de ideias, é importante perceber que, do ponto de vista indígena, a ingestão do outro, permite que haja uma apropriação cultural da sua morte, já que, permanecendo no outro, ele escapa ao desaparecimento. Mantendo-nos ainda sob a perspectiva indígena, inferimos que homem pode, e deve, subtrair seu semelhante a essa outra dimensão natural, a tal ponto ameaçadora da cultura (da memória), que quase pode constituir-se como uma outra cultura diferente da anterior. Esclarece-se assim que há quase uma disputa, da morte na natureza anônima, sem memória, que tudo engole, sem nada preservar - e a cultura - identitária, que constrói a memória e faz do sacrifício antropofágico uma forma de preservação do outro. Torna-se, portanto, evidente como, nessa perspectiva, a natureza nunca se configura como dimensão meramente natural, materialista, mas é sempre, e de várias formas, edificada em relação à cultura com a qual interage.

A afinidade entre valor nutritivo e valores simbólicos é, portanto, um mecanismo complexo que reforça e responde à complexidade das hierarquias sociais. Quanto mais o rito alimentar assume essa configuração complexa, tanto mais impregna-se de valores simbólicos dificilmente subordináveis ao valor nutritivo. O condicionamento que recebemos dessa pequena rede simbólica oculta condiciona nossas escolhas alimentares, ao ponto que alimentos e práticas alimentares, diferentes das nossas preferências culturalmente dadas, podem provocar um tal descontentamento, de outra forma não compreensível. O próprio "choque cultural" do explorador, do etnólogo, do missionário ou do colonizador, enfim do "estrangeiro", face a uma prática alimentar desconhecida, transforma-a em um signo de "barbarização", de ausência de civilização ou, pior ainda, faz dela o signo privilegiado da ausência de humanidade.

Uma das funções principais do ato de comer carne humana consistia, portanto, em adquirir uma condição humana justamente pelo meio de um controle e de uma conquista cultural da morte, por meio da representação do inimigo, dos ritos sacrificiais e das práticas alimentares antropofágicas. Há no interior dessa prática o controle da morte que opera em direção de uma construção e afirmação da identidade. Dessa forma, a identidade cultural Tupinambá é sempre posta em jogo pela alteridade, a qual, por consequência, constitui necessariamente o próprio núcleo da identidade. Ao assumirem essa "identidade na alteridade", cremos, que há um consequente esboço da característica que responde ao modelo cultural indígena. Exclusivamente assim é que os "guerreiros" tinham acesso ao mundo dos mortos, com as divindades e os heróis civilizadores. Instigante, se nos detivermos na caraterização linguística dos Tupinambá, os mortais comuns (mortos de morte natural) são "verdes", "crianças", afinal "crus".

Em citação feita por Adone Agnolin do texto de Florestan Fernandes a respeito do povo indígena, percebemos, claramente, como tal percepção linguística se desenha como representação de uma ideologia, pois:

${ }^{2}$ Canibalismo entre pessoas de uma mesma tribo.

${ }^{3}$ Canibalismo praticado sobre indivíduos de tribos estranhas. 
É necessária a morte (ritual) e o cozimento (sacrificial) para que amadureçam, cresçam e se completem. E, antes disso, os "viventes" tornavam-se "homens" (avá) só quando tivessem conseguido aprisionar um inimigo e sacrificá-lo ritualmente: isso constituía o pressuposto que criava "o direito de passar pelos rituais que dariam acesso ao status de 'homem'" (FERNANDES: apud AGOLIN, 1970,149) .

Dessa forma, ingerir carne humana, longe de ser um simples hábito alimentar, apresenta traços de uma cultura que quer se manter viva e aprimorada por meio de seus ritos e cerimônias. Se a reprodução da comunidade indígena surge por causa da exigência de neutralizar a ameaça do estranho através de sua incorporação, os bens da troca se caracterizam como termos de uma mediação que é, ao mesmo tempo, diferenciação e assimilação. O que torna significativa a análise do ritual sacrificial é o fato de que a alteridade do inimigo/vítima pode ser introduzida e, até um certo ponto, assimilada na vida da aldeia.

Partindo dessa análise, vale a pena pensar que, se esta relação entre mito e rito se coloca de modo diferenciado, da mesma forma, nas várias culturas e nos sistemas sociais humanos, parece se constituir como um "dado", a função das escolhas e dos comportamentos alimentares que visam à caracterização interna da cultura, em separação do que é externo. Contudo, se esses dois processos nunca se constituem por si só, e se o externo contribui substancialmente para produção do interno, a cultura Tupinambá também determina e funda, em suas atitudes, as características imutáveis do "bom" gentio que lhe garantem o fundamento de sua identidade e o espaço de sua ação cultural. Nesse sentido, o rito antropofágico configuraria os "selvagens canibais", como partícipes do estado de natureza ou de seu próprio desejo. Operando através do ritual e compelidos por seu canibalismo, os indígenas manifestam, no entanto, sua necessidade fundamental (real e culturalmente proteica) de viver em sociedade, continuando a alimentar a própria cultura em seus fundamentos míticos através de sua ação ritual. Podemos, dessa forma, perceber que, na ação final de assimilação antropofágica, através dos procedimentos rituais, manifesta-se de modo evidente a bipolarização identidade/alteridade que acaba reforçando a alteridade do inimigo que se torna, enfim, comida para os outros. Ao alimentar-se dessa alteridade, não se efetuava uma destruição literal, e, sim, uma transformação: quem comia adquiria a qualidade do outro que, por sua vez, ia se configurar, como o túmulo (cultural) que lhe teria sido permitido subtrair-se a uma desonrosa morte na natureza. Esse processo se constitui, portanto como uma recíproca transformação, tanto de quem é assimilado, quanto de quem assimila.

Para o colonizador, em nosso caso, em sua grande maioria, os portugueses, os índios eram seres ignorantes, atrasados e causadores de imensa decepção por não se encaixarem aos planos desse colonizador no tocante à submissão ao trabalho. Na carta escrita por Caminha ao rei de Portugal, enunciava-se a pretensa superioridade com que os portugueses lidavam com a população do Brasil. Os nativos sempre vistos como inferiores diante dos olhares dos conquistadores que eram guiados segundo um sistema de regras e leis definidas pelo cristianismo. A ideologia religiosa é, para Caminha, o aspecto mais importante nessa relação. Por não reconhecer nos

${ }^{4}$ É interessante observar como o sacrifício adquire a possibilidade de representar e sintetizar (ou seja, de produzir) todo o processo cultural. Isto é confirmado pelo fato que "graças às relações e às obrigações de parentesco, alguns jovens não se submetiam às provas 'militares'; limitavam-se a sacrificar um inimigo, recebido de 'presente' do seu pai, ou do marido da irmã, e a passar pelos ritos subsequentes de renomação" (FERNANDES, 1970: 149-50). 


\section{Roberta maria Ferbeira Alves}

$1 \circ$ SEMESTRE DE $2020-$ N. 36

nativos uma cultura própria, os portugueses pretendiam torná-los súditos cristãos do rei de Portugal. Tais colonizadores, de acordo com os padrões europeus, eram incapazes de entender os índios e o seu contexto sociocultural, reduzindo-os à condição de selvagens. Dessa forma, por um longo período, o indígena brasileiro foi visto e percebido pela ótica do colonizador e, assim, excluído culturalmente da formação de nossa identidade nacional.

Dialogando com uma ideologia impregnada de preconceitos contra o selvagem e o colono, supervalorizando o colonizador como "o civilizado", narrativas da América, em seu projeto de formulação da nacionalidade, deixam-se penetrar por um conceito de identidade marcado pela tradição europeia. Nas artes, especificamente, na literatura, alguns autores tentaram inserir a cultura autóctone e os nativos brasileiros em sua produção, contudo, apenas em Alencar, percebemos um caminhar diferenciado em direção de uma modificação de postura. Há uma tentativa de construção de uma visão menos colonizadora do nativo e de uma identidade nacionalmente brasileira. Vale ressaltar que, embora o escritor cearense buscasse a valorização do elemento indígena como um fator importante de uma identidade tipicamente brasileira, para ele a cultura indígena deveria fenecer para nascer uma cultura nacional civilizada.

Caso busquemos uma possível "origem" do nacional, é no romance indianista de Alencar que percebemos a "fundação" de uma paisagem, um marco aprazível que podemos nomear como "Brasil”, "origem", "natureza”. Todavia, esta origem é da ordem do discurso, o que permite que a "paisagem do discurso" e a realidade político-social conflitem. Inseridos nesse contexto, inferimos que, além das diferenças geográficas, havia também diferenças de objetivos em suas relações com diferentes configurações do poder. De uma forma mais específica, opunham-se a dificuldade de conciliação entre um trono à europeia, marcado ainda por traços dinásticos e uma nação que se desenhava a partir de um ideal de liberdade tão exuberante quanto as forças da natureza. Durante o século XIX, um modelo de sucesso, que deu corpo ao projeto americano de escrever a nação, foi desenhado, associado aos processos de independência e da necessidade de implantar estruturas sociais estáveis que garantissem a formação de um Estado, "verdadeiramente" nacional.

Vale ressaltar que Alencar não pode ser percebido como "referência essencial" nessa desconstrução em sua maneira de vislumbrar o índio, visto que, por questões óbvias, ainda traz na descrição de seus personagens indígenas visões europeizadas. Contudo, o cearense pode funcionar como um guia que, distribui equitativamente por todo o Brasil, uma visão valorizada desse indígena, produzindo um efeito unificador da nossa nacionalidade como representação e memória coletiva. Na verdade, seu nome é sempre referência quando pensamos em nação brasileira e o povo nativo que aqui habitava antes da colonização europeia.

O romancista cearense acalenta/acalentou ousado projeto de fundação do nacional, através do qual busca preencher o relativo vazio de estruturas sócio-políticas da nação ainda em embrião. Em outras palavras, o projeto de independência que o romance de Alencar ratifica interconecta, como seus personagens indígenas, o autóctone com uma figuração fantasmática dessa mesma autoctonia, já que essa era focalizada, simultaneamente, tanto a partir de signos de um olhar europeu que a desqualificava, quanto a partir da valorização da nacionalidade em sua representação de cor local. 
Cremos que esse projeto ambicioso não tenha conseguido em seu tempo se estabelecer, se tornar completo e alcançar a plenitude desejada, mesmo porque essa plenitude nunca seria encontrada. Esse projeto, no entanto, consegue ultrapassar o tempo e o espaço e ecoar de forma espraiada no século XX, seja como exemplo do que deve ser feito ou do que deve ser evitado.

O Romantismo, estética literária de Alencar, e o Modernismo foram movimentos estéticos que, à sua maneira, trabalhavam temas como o nacionalismo, identidade nacional, valorização e ou análise da origem de um povo e da história de um país. Sendo nacionalista e historicista - postulando um respeito às particularidades históricas e culturais das nacionalidades -, o romantismo foi o encaixe perfeito às necessidades políticas, estéticas e ideológicas da elite intelectual brasileira do século XIX que, tendo formalizado a independência (pelo menos oficial) do Brasil, necessitava criar um discurso identitário próprio. Uma adaptação bem nacional pode ser percebida no fato de que no Brasil o historicismo romântico dirigiu-se ao passado indígena, eleito, em muitos momentos, como elemento unificador da identidade nacional, enquanto na Europa o mesmo historicismo romântico se debruçou sobre a Idade Média. Essa dita identidade nacional, brasileira, no entanto, esteve quase sempre comprometida com símbolos da cultura europeia: o índio de "bons sentimentos portugueses", como dizia Oswald de Andrade em seu "Manifesto Antropófago".

Seria um tanto abusivo afirmar que a dessacralização do nacionalismo sublime encontraria pleno conforto nos discursos de nacionalidade do modernismo. Sabemos que no modernismo foram produzidas a paródia, a piada, a dessacralização dos purismos verbais, e mesmo assim não podemos afirmar que essa estética foi opositora contumaz aos cânones do romantismo, e sim, resultado de inúmeras reverberações, pois,

[...] a redescoberta do país pelos modernistas os fazia retomar a bandeira há várias décadas empunhada por Gonçalves de Magalhães, Porto Alegre, Gonçalves Dias e Alencar. Voltavase à premissa romântica da literatura nacional. Não foi com olhos assim românticos que os modernistas paulistas descobriram o barroco mineiro, a humilde sobriedade de suas velhas cidades e a excepcionalidade do Aleijadinho?" (LIMA, 1991, p.243).

Claro que a "redescoberta" do Brasil pelos modernistas passava por outra perspectiva ontológica. Se no romantismo dominante, o Brasil era visto como uma essência pura, como um "interior" a ser "exteriorizado", como querem Silviano Santiago (1991) e Roberto Corrêa dos Santos (1999), no modernismo o interior brasileiro é compreendido como algo que escapa à ideia de a essa essência identitária pura.

Estamos nos referindo, especificamente, ao modernismo vinculado a Mário e Oswald de Andrade, seus pares, e não ao modernismo do verde-amarelismo, fascista, cunhado a partir da crença em uma integridade do caráter nacional.

Mesmo assim, nas linhas do "Manifesto de Poesia Pau-Brasil", não há um completo rompimento com o espírito romântico que o antecedeu, pelo contrário, o texto se insere em sua tradição. Fatalmente traremos Alencar que afirmava na "Carta ao Dr. Jaguaribe”: “... é preciso que a língua civilizada se molde o quanto possa à singeleza primitiva da língua bárbara...” (1987, p. 84). 


\section{CESPUC}

É necessário olhar de modo plural a proposta oswaldiana, "ver com olhos livres" tanto para a vida moderna, como para a produção cultural da modernidade, para que se possa encontrar, no modernismo brasileiro dos anos 1920, uma coexistência de tradição e modernidade. Ao mesmo tempo em que estavam imbuídos de espírito "futurista" e da necessidade de atualizar as referências culturais brasileiras, os modernistas se preocupavam com o resgate do passado do país. Como exemplo disso, temos a viagem às Minas Gerais realizada (1924) pelo grupo modernista de São Paulo. No momento em que recebiam o poeta Blaise Cendras, signo da vanguarda literária, os modernistas viajavam, ao lado do poeta suíço, rumo à tradição da vida colonial do século XVIII e do barroco mineiro. Essa viagem teve grande ressonância na produção cultural modernista. Fica perceptível que Oswald de Andrade a incorpora ao seu Poesia pauBrasil, dedicando uma das secções do livro à captação e exibição de instantâneos fragmentários do "Roteiro das Minas". Silviano Santiago (2002) aponta, como um dos resultados da viagem, a necessidade, sentida por Mário de Andrade e Tarsila do Amaral, de não apenas atualizar a cultura brasileira, mas também de "conservá-la" e "restaurá-la".

Após 4 anos dessa viagem pelas entranhas de Minas Gerais, é publicado o mais radical manifesto cultural e político do início do século XX no Brasil, "Manifesto Antropófago", de Oswald Andrade. Nele o paulistano lança mão, a partir da ideia de antropofagia, de uma visão crítica da herança cultural ocidental, cuja oposição está diretamente relacionada à ideia de cópia da cultura estrangeira em detrimento da cultura nacional, o binômio cópia/original. No Manifesto, é explorada a noção antropofágica como metáfora para a transformação da cultura ocidental: deglutir o que vem de fora e transformar em algo totalmente novo; absorver o inimigo sacro, escapando às dicotomias nacional/estrangeiro, escola/floresta. A popularização da antropofagia oswaldiana só aconteceu a partir da década de 1950, com a reunião do concretismo dos irmãos Campos, o Cinema Novo de Glauber Rocha, o Teatro Oficina de José Celso Martinez Corrêa, as artes plásticas de Hélio Oiticica, até desembocar finalmente no mais popular desses movimentos: a Tropicália de Caetano Veloso, Gilberto Gil e Torquato Neto. Dessa maneira refletir sobre esse pensar antropofágico como rito de assimilação que surge nos Tupinambá, passa por Oswald de Andrade e chega, ou atravessa o cenário artístico-cultural brasileiro, especialmente em suas reverberações no cancioneiro nacional.

Em 1967 uma instalação, na exposição de Hélio Oiticica no Museu de Arte Moderna do Rio de Janeiro (MAM-RJ), é responsável pelo termo que nomearia o movimento tropicália que funcionou principalmente como um divisor de águas para a música popular brasileira. 
Figura 1: Tropicália

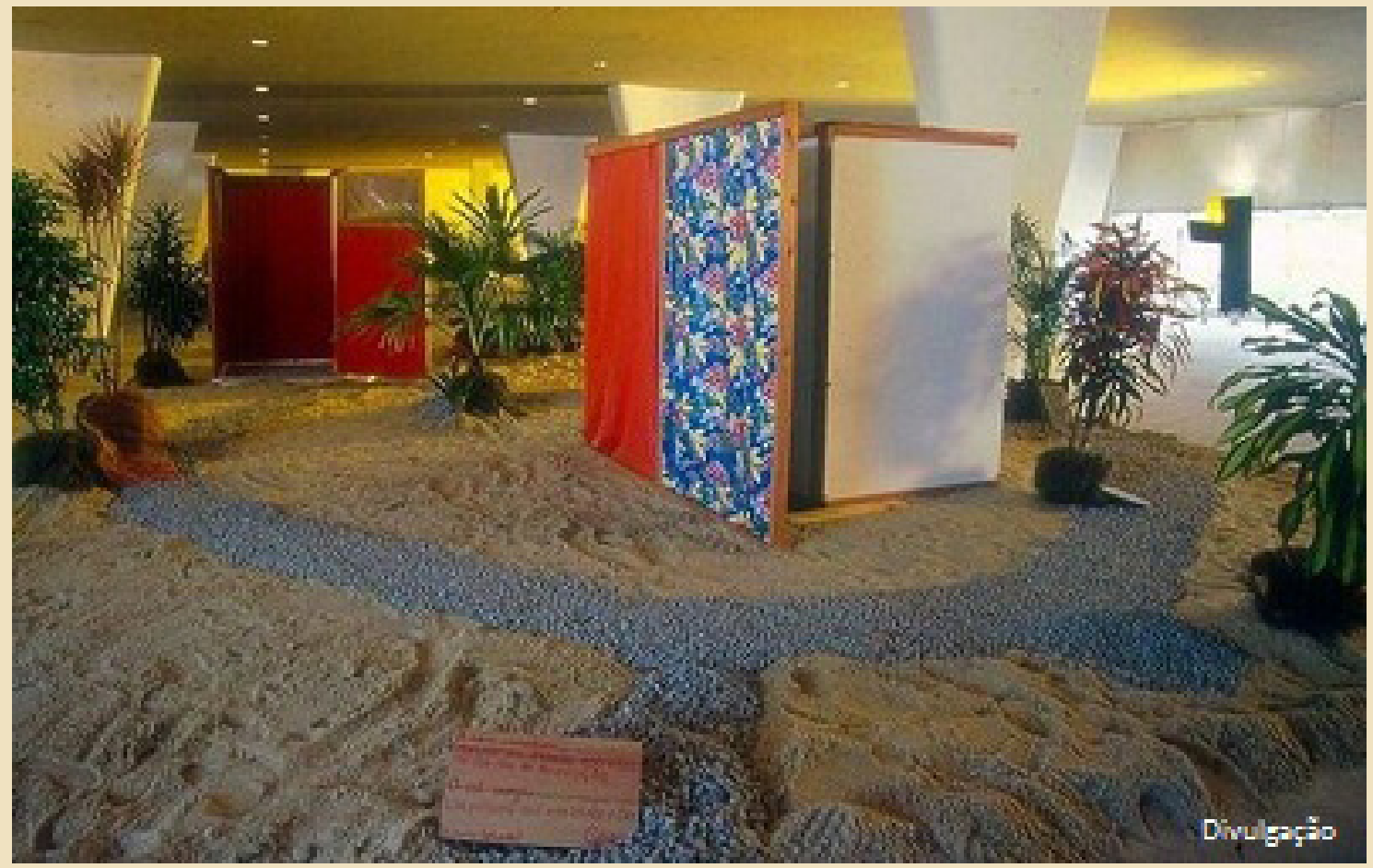

Fonte: http://www.multirio.rj.gov.br/index.php/leia/reportagens-artigos/reportagens/12929-por-quecomemorar-os-50-anos-do-tropicalismo

Analisando a imagem anterior vemos uma instalação com um ambiente labiríntico composto de dois Penetráveis, PN2 (1966) - Pureza É um Mito, e PN3 (1966-1967) - Imagético, associados a plantas, areia, araras, poemas-objetos, capas de Parangolé e um aparelho de televisão. Segundo Oiticica

o ambiente criado era obviamente tropical, como num fundo de chácara e, permitindo a sensação de que se estaria de novo pisando na terra. Esta sensação sentira eu anteriormente ao caminhar pelos morros, pela favela, e mesmo o percurso de entrar, sair, dobrar pelas 'quebradas' de tropicália, lembra muito as caminhadas pelo morro. As imagens tropicais donde o título - são evidentes: areia, araras, as plantas.

(OITICICA, in enciclopedia.itaucultural//termo3741/tropicalia)

A instalação cria um convite tácito ao observador para que participe do processo e o percorra. Ambiente dissonante que "ruidosamente apresenta imagens", segundo o seu criador, invadindo todos os sentidos, solicita companhia para dividir a experiência. O Brasil se faz presente na escolha e utilização de signos e imagens que percebemos associadas à nossa terra, o que não deixa de ser uma idealização do que sejam nossos emblemáticos desenhos nacionais Oiticica se propôs delinear uma imagem brasileira através da "devoração" dos símbolos da cultura brasileira. Tal ideia, de "devoração", é o liame que nos remete diretamente à retomada da antropofagia e ao modernismo em sua vertente oswaldiana. 
A Tropicália, então, na década de 1960, transformou-se em uma nova maneira de pensar que inundou a produção do artista de Oiticica e se espalhou para a música a partir do momento que o artista plástico descobre o samba, a Mangueira e a arquitetura particular das favelas a que Tropicália faz referência.

O projeto e a realização da "Tropicália" ecoam em outras manifestações artísticas do período: no cinema, no teatro, e na música popular criada pelo grupo reunido em torno de Caetano Veloso, Gilberto Gil e Torquato Neto. Vale ressaltar que o nome da instalação também batiza uma canção e o álbum musical de 1968, nomeando em seguida um movimento cultural mais amplo, o tropicalismo.

Valorizando e respeitando as diferenças específicas existentes entre as diversas formas de manifestações artísticas e a variada produção abrigada sob o rótulo, as produções tropicalistas compartilham o experimentalismo característico das vanguardas com o tom de crítica social. Em todas elas, a mesma tentativa de superar as oposições completivas arte/vida, arte/antiarte.

Cremos que seja possível estabelecer um diferença básica e plausível entre as duas propostas que analisamos, ou seja, a proposta antropofágica modernista e a tropicalista; aquela depositava seu principal interesse em digerir a cultura erudita que estava sendo importada e, essa, assume a incorporação de todo tipo de referencial estético, tanto erudito quanto popular.

Nosso caminho pelo movimento tropicalista aqui se afunila e direcionamo-nos especificamente para a questão da música popular. Esse movimento rompeu estruturas definidas e sacudiu o ambiente do cancioneiro brasileiro entre os anos de 1967 e 1968, período extremamente crítico em nosso cenário político nacional como também no cenário político internacional. O grupo, que foi responsável por essa guinada, era formado por

Caetano Veloso e Gilberto Gil, além das participações da cantora Gal Costa e do cantorcompositor Tom Zé, da banda Mutantes, e do maestro Rogério Duprat. A cantora Nara Leão e os letristas José Carlos Capinan e Torquato Neto completaram o grupo, que teve também o artista gráfico, compositor e poeta Rogério Duarte como um de seus principais mentores intelectuais. (http://tropicalia.com.br/identifisignificados/movimento)

Os tropicalistas, funcionaram como um divisor de águas na música nacional. Vale lembrar que o nosso cenário musical, então, estava "dominado" por padrões estéticos, ou melhor dizendo o que era valorizado como "qualidade musical" estava ligado às posições tradicionais e nacionalistas. Os tropicalistas funcionaram como contraponto a essas tendências, buscando universalizar a linguagem da música popular brasileira (MPB) a que acrescentaram elementos da cultura jovem mundial, como o rock, a psicodelia e a guitarra elétrica. Simplesmente tudo teria lugar na Tropicália, uma "devoração" completa da tradição e da novidades, do nacional ao estrangeiro.

Tudo isso em associação a uma sintonia particular com as informações da vanguarda erudita revisitadas por arranjos diferenciados dos maestros Rogério Duprat, Júlio Medalha e Damiano Cozzela. Uma junção nunca executada que unia o popular, o pop e o experimentalismo estético, impulsionando a modernização da música e da cultura nacional. 
Trabalhos complexos e de qualidade extrema efetuavam "conversas" com obras literárias. Em tais diálogos percebemos relações explicitas com os versos seiscentistas de Gregório de Matos, com a obra de Oswald de Andrade e com a produção dos poetas concretos paulistanos. As canções que resultaram dessa conversa eram responsáveis por um novo desenho crítico e complexo do nosso país. Um palimpsesto constituído por um Brasil arcaico e suas tradições, outro moderno e sua cultura de massa, e ainda um país futurista repleto de astronautas e discos voadores.

Um momento de sincretismo e inovação no qual havia misturas aparentemente heterogêneas com doses de rock, bossa nova, samba, rumba, bolero e baião, numa tentativa de romper fronteiras entre o pop e o folclore; alta cultura e cultura de massas; tradição e vanguardas. Tendo a irreverência como arma principal o movimento transformou critérios de gosto vigentes na música, na política, na moral, no comportamento na maneira de percepção do corpo, do sexo e do modo de vestir, uma assimilação da contracultura hippie. Cabelos longos encaracolados, desalinhados e roupas escandalosamente coloridas auxiliavam a compor a imagem desse movimento. Infelizmente a duração pequena desse arroubo de liberdade ocorreu durante a repressão imposta pelo governo militar. Prisões, deportações e censura determinaram seu fim, mas não a marca de ter sido uma redescoberta de uma face identitária absolutamente moderna e tropical.

O movimento que, embora seja resultado de um conjunto de mentes e diálogos, está ligado de forma bem delineada a Caetano Veloso, compositor baiano, que eu seu livro Verdade Tropical (1997), um texto que se aproxima de uma autobiografia, apresenta suas influências e percepções sobre esse marco da MPB chamado tropicalismo que

começou em mim (Caetano) dolorosamente. O desenvolvimento de uma consciência social, depois política e econômica, combinada com exigências existenciais, estéticas e morais que tendiam a pôr tudo em questão, me levou a pensar sobre as canções que ouvia e fazia. Tudo que veio a se chamar tropicalismo se nutriu de violentações de um gosto amadurecido com firmeza e defendido com lucidez. (VELOSO, 1997, p.254)

A letra da canção de Caetano Veloso, "Tropicália” (1968), emblematicamente se desenha como uma construção decodificada por um pensar marcadamente antropofágico. Segundo o compositor baiano, ao assistir uma encenação de $\mathrm{O}$ rei da vela, de Oswald de Andrade, dirigida por José Celso Martinez Corrêa do Teatro Oficina, percebeu algo além do visível: "Eu tinha escrito "Tropicália" havia pouco tempo quando O rei da Vela estreou. Assistir a essa peça representou para mim a revelação de que havia de fato um movimento que transcendia o âmbito da música popular." (VELOSO, 1997, p. 244) Esse foi o momento epifânico do encontro, início de um diálogo direto que se delineava.

O baiano de Santo Amaro da Purificação, em conversa, nesse mesmo período, com o diretor Augusto Boal e diante da preferência desse por Vianinha, (Oduvaldo Vianna Filho), dramaturgo brasileiro, oriundo do CPC e da $\mathrm{UNE}^{5}$ afirma que:

Ora, para mim Oswald estava apenas nascendo, e suas figuras pareciam disparatadas ${ }^{5}$ Centro Popular de Cultura e União Nacional dos Estudantes. 
justamente, porque em vez de servir como ilustração para idéias supostamente indiscutíveis instigavam a imaginação a uma crítica da nacionalidade, da história e da linguagem. Em breve eu descobriria que o teatro de Oswald de Andrade era a parte mais fraca de sua obra - e O rei da Vela, talvez a parte mais fraca do seu teatro Tudo o que eu vira ali, estava melhor posto em sua poesia, seus romances e seus manifestos. (VELOSO, 1997, p.246)

A partir dessa declaração feita, Boal insistiu que Caetano se aproximasse dos poetas concretos. Contudo, nas próprias palavras do baiano, os irmãos Campos e Décio Pignatari já bebiam da fonte oswaldiana do pensar, como o José Celso. O devorar da obra oswaldiana era o ponto comum entre eles.

Porém, é em sua leitura do manifesto de 1928, que o músico encontra o "caminho das pedras”, pois segundo Caetano é nesse momento, no segundo manifesto que Oswald:

Desenvolve e explicita a metáfora da devoração. Nós brasileiros, não deveríamos imitar e sim
devorar a informação nova, viesse de onde viesse, ou, nas palavras de Haroldo de Campos,
"assimilar sob espécie brasileira a experiência estrangeira e reinventá-la em termos nossos,
com qualidades locais ineludíveis que dariam ao produto resultante um caráter autônomo e
lhe confeririam, em princípio, a possibilidade de passar a funcionar por sua vez, num confronto
internacional, como produto de exportação. (VELOSO, 1997, p. 247)

Segundo Caetano, para os tropicalistas a "ideia de um canibalismo cultural" servia-lhes "como uma luva". A proposta básica desses artistas era comer de Beatles a Jimmy Hendrix, de Luiz Gonzaga a Villa Lobos. Sabemos que anos e acontecimentos se colocaram entre a proposta de Oswald de Andrade e a proposta dos tropicalistas, mas cremos que no fundo entre manifestações, vaias e verduras no Municipal de São Paulo e embates televisivos e do mundo fonográfico dos tropicalistas, as propostas estiveram permanentemente em diálogo, seja em forma de reverberações, repetições, aprimoramentos ou simplesmente alusões.

No profícuo encontro entre os antropófagos: o tropicalista e o modernista, em gesto confessional aquele afirma que lhes serviram de inspiração os poemas curtos, os ready-mades extraídos das cartas de Caminha, para um repensar do que era conhecido sobre a "literatura brasileira", poesia brasileira, sobre arte brasileira, sobre o Brasil em geral, sobre arte, poesia e literatura em geral. (Cf. VELOSO, 1997, p. 256-257).

E Caetano soube, à sua maneira, devorar esse “antropófago indigesto” que, em suas palavras, "a cultura brasileira rejeitou por décadas, e que criou a utopia brasileira de superação do messianismo patriarcal por um matriarcado primal e moderno, tornou-se para nós o grande pai." (VELLOSO, 1997, p.257).

Através de uma leitura própria da letra da canção "Tropicália" (1968), de Caetano Veloso, levantaremos possíveis aproximações e distanciamentos dos movimentos rituais e antropofágicos.

A canção escolhida, além de nomear o movimento, explicita as propostas nas quais ele se apoia e em que acredita. A princípio uma canção que se alimentou da ideia exposta em um samba intitulado "Essas coisas nossas" (1932), de Noel Rosa. Em diálogo com o herói híbrido e 
sem caráter definido de Mário de Andrade, a canção que pretendia traçar um panorama do que significava ser brasileiro durante algum tempo, não era substantivada. Tal canção intitulada, inicialmente "Mistura Fina", por questões de falta de opção e imposição se tornou "Tropicália", e está incluída no LP Caetano Veloso, de 1968. Trata-se de uma composição caleidoscópica e palimpséstica evocando diversas referências, através de diálogos entre o arcaico e o moderno, o cosmopolita e o periférico, o atraso e a vanguarda, o artesanato e a indústria. A letra cubista relaciona basicamente a diversidade do Brasil e seus símbolos, com a tropicália e sua diversidade musical. A melodia é uma mistura de influências que nos remetem, ao mesmo tempo, ao rito antropofágico dos nativos brasileiros e do movimento modernista. Acordes dissonantes compõem um universo que une sons emitidos por instrumentos musicais tidos como nacionais, e estrangeiros, principalmente se nos referirmos aos instrumentos de percussão, daqueles ao som elétrico e energizado das guitarras que metonimicamente representam o imperialismo britânico e estadunidense.

O compositor baiano tenta explicitar, ao longo da canção, o que é a tropicália, e nesse momento, percebemos nitidamente as aproximações e similitudes com traços de nosso país. A canção é, especularmente, a concretização sonora do país embora as palavras sejam as detonadoras de imagens que compõem o cenário/partitura. A canção Tropicália rompe com paradigmas poéticos construindo em seus versos imagéticos um mosaico da cultura brasileira, embora o autor afirme em seu livro, já citado, que não quis fazer um mero inventário do ser nacional. No processo de criação da letra da canção, "as palavras encontravam rimas; As ideias, contrastes e analogias; as imagens, espelhos lentes, e ângulos insustentáveis.” (VELOSO, 1997, p. 185)

Sob o arranjo do maestro Júlio Medaglia, os sons, no início pouco audíveis, que nos remetem à floresta e aos nativos que dela se originam, aos poucos se transformam em um som mais forte e misturado com instrumentos de origens diferenciadas, o que nos faz ouvir, como que em um resgate pertinente, os nativos, e o moderno revisitados. A voz humana do Dirceu, ${ }^{6}$ baterista, como um coro grego, debochado, anuncia em tom solene, uma representação de nascimento do país, uma (re)leitura desse momento, como se acontecesse um redescobrir do Brasil, um redescobrimento musical e cultural:

\author{
Quando Pero Vaz Caminha \\ Descobriu que as terras brasileiras \\ Eram férteis e verdejantes, \\ Escreveu uma carta ao rei: \\ Tudo que nela se planta, \\ Tudo cresce e floresce. \\ E o Gauss7 da época gravou (VELOSO, 1997, p.186)
}

\footnotetext{
${ }^{6}$ Vale ressaltar um pequeno detalhe sobre esse trecho se encontra detalhado por Caetano em seu livro Verdade tropical. Segundo o compositor baiano, dia da gravação, da única canção do LP que não tinha título, o baterista Dirceu, ao ouvir a introdução, lembrou-se da carta de Caminha e improvisou, sem se dar conta que estava sendo gravado pelo técnico de som Rogério Gauss.

${ }_{7}$ O Gauss do tempo da canção, o técnico de som, e não, o Gauss de ontem (séc. XVIII), um matemático, astrônomo e físico alemão que contribuiu muito em diversas áreas da ciência, dentre elas a teoria dos números, estatística, análise matemática, geometria diferencial, geodésia, geofísica, eletroestática, astronomia e óptica.
} 
Um pacto se estabelece com o público e uma viagem se inicia, partindo da viagem ultramarina. Tal viagem não é apenas aquela das caravelas de Cabral que partem do Tejo em direção ao Novo Mundo, nem a de Staden pela cultura Tupinambá, nem tampouco a de Cendras e dos modernistas pelas penhas de Minas. A viagem agora proposta parte do litoral para o interior do país. Um convite para inaugurar um monumento/movimento que celebra todas essas viagens em uma só. As práticas musicais da canção são saturadas de representações, formando um rico quadro histórico brasileiro. Logo na primeira estrofe, há um convite para a resolução de um enigma paradoxal que é levado ao longo de toda composição:' Sobre a cabeça os aviões//sob meus pés os caminhões//aponta para os chapadões//meu nariz"

O trecho anterior é apresentado em uma melodia orquestral, enérgica e vibrante na qual percebemos um jogo entre as máquinas representantes do contexto brasileiro da industrialização e modernização em contraste com o arcaico da estrofe que abre a canção.

Quem é esse sujeito lírico? Quando e de onde fala? Um ser capaz de tocar os céus e ter sob seus pés caminhões. É ele um ser gigantesco humanoide? Um sujeito que pode nos remeter ao Gigante Adamastor no Canto V de Os Lusíadas, de Luís de Camões, que, inspirado em Homero e Ovídio, é o mais rico e complexo do poema. De natureza simbólica, mitológica e lírica. No fragmento mencionado, deparamo-nos com o real maravilhoso, repleto de lirismo, culminando em um enredo trágico de amor e morte, um episódio épico no qual se consolida a vitória do homem sobre os quatro elementos (terra, fogo, água e ar).

Nesse diálogo temporal, "ontem”, no presente da canção ou em nosso futuro/ presente há o vislumbre daquele momento do passado? Uma realidade paradoxal que permite que aviões, símbolo de modernidade coexistam com caminhões? A modernidade em diálogo desigual com a ausência de tecnologia que ainda traz sombra a alguns locais esquecidos. A atitude de apontar o nariz, numa clara demonstração de intromissão ou de autonomia, indica a direção para onde se voltam as questões que serão discutidas no decorrer da canção, um Brasil mais amplo que não se detenha em lugares litorâneos sempre vistos, o Brasil de dentro. E esse interior nos remete às problemáticas que envolvem a constituição daquilo que entendemos como cultura brasileira. É na ausência de limites, nesse trânsito entre o moderno e o arcaico que serão colocadas as questões mais candentes da identidade cultural do Brasil, uma questão atemporal. Estruturada em uma constelação de diálogos nos quais o sujeito se coloca em posturas díspares e complementares, analisando de forma crítica essas aproximações e distanciamentos de um contexto experienciado/criado.

Os versos seguem e o sujeito lírico se coloca no lugar de quem terá a tarefa de "organizar" o que se encontra desorganizado, o "milagre econômico", a inauguração da nova capital no interior do país,

eu organizo o movimento

eu oriento o carnaval

eu inauguro o monumento

no planalto Central

do país

(VELOSO in letras.mus.br) 
Ainda na mesma linha melódica, na sequência nos deparamos com esse sujeito lírico polifônico que traz, (re)elabora as linhas paradoxais que possivelmente são constituintes de uma identidade brasileira. Na fala do eu lírico, intrometem-se vozes contrapostas, indiciadas pelos substantivos monumento e movimento. Uma menção ao movimento que está se fazendo presente no cenário nacional, o próprio Movimento Tropicalista que intenta redesenhar a cultura nacional levando em consideração todas as manifestações e influências da cultura brasileira como legítimas, uma vez que essa cultura é antes híbrida do que homogênea.

Mais uma vez vem à tona a ideia de um gigante mitológico que pretende "orientar" o carnaval. Em nosso ponto de vista, uma atitude bem hercúlea, possível apenas para grandes heróis, contudo, se por um acaso percebermos o carnaval como uma festa popular, nascida nas ruas, a tarefa pode ter seu sentido deslocado. A festa de momo que, inicialmente foi vista como desprovida do valor cultural nele encerrado, diante do fato de o sujeito lírico assumir organizar a festança momesca, pode, também, nos remeter a ideia de colocá-lo no lugar que merece, o de importante manifestação cultural nacional. (Re)valorizar o conjunto de manifestações da cultura popular, que segundo Bakhtin, é "um espetáculo ritualístico que funde ações e gestos elaborando uma linguagem concreto-sensorial simbólica." (Bakhtin, 1981: 105). Ainda sob a ótica do teórico russo, é no carnaval que o sentimento individual faz parte da coletividade, tornando-se integrante de do grande corpo popular. A unidade coletiva constituise pela dissolução das identidades individuais. O corpo individual deixa, até certo ponto, de ser ele mesmo e se une aos demais ao travestir-se por meio de fantasia e máscara - exigência a todos os corpos individuais para formar um único corpo. Apesar da troca e do pretenso abandono individual o povo sente as suas unidade e comunidade concretas, sensíveis, materiais e corporais.

Ao se colocar na posição daquele que organiza algo que é uma exaltação à desordem, à inversão, esse eu múltiplo, se manifesta ironicamente como um elemento contraditório, e, talvez por isso, um representante legítimo dessa nação desenhada. Ele se permite organizar um movimento que ressignifica o cânone, orienta algo que é uma apologia à desorientação e, finalmente inaugura monumentos que em nome do progresso fixa cada vez mais as diferenças contrastivas que existem no país.

O monumento é uma imagem recorrente ao longo da canção. Remetendo-nos à Brasília, a capital federal sonhada por Juscelino Kubistchek e projetada por Oscar Niemeyer, Lúcio Costa, Burle Marx, Israel Pinheiro, Bernardo Sayão e Ernesto Silva, símbolo da modernização crescente que vinha sendo implantada no país, além de, depois, símbolo materializado do "Milagre Econômico" brasileiro. Percebemos um sujeito lírico que se preocupa tanto com as questões que envolvem as identidades do povo quanto com as questões ligadas à estética modernista. O refrão torna-se, então, uma síntese da primeira parte da canção no qual nos deparamos com uma estrutura rítmica e melódica drasticamente modificada; o ritmo lembra algo do baião ou do xaxado. Essa quebra continuará a se repetir até o final da música, entre estrofes e refrões, simbolicamente alterados: Viva a bossa sa sa// Viva a palhoça ça ça ça ça.

São exaltados aqui, sem que haja hierarquização, o arcaico e o moderno. A utilização de palavras em parte homófonas, permite-nos uma distinção, mas não uma valorização de uma 
em detrimento da outra, uma forma híbrida de desenhar esse solo e esse povo tão mesclado. Trata-se de uma cabeça de Jano que é constituída de duas forças paradoxais, enquanto uma está focada no passado, outra vislumbra o futuro. O termo "bossa" faz alusão tanto à Bossa Nova, movimento musical surgido no Rio de Janeiro e apreciado pela juventude urbana, quanto à gíria utilizada no Rio de Janeiro nos anos 30 e que já aparecia no samba de Noel Rosa chamado "São coisas nossas", além do programa de televisão "O Fino da Bossa" liderado por Elis Regina e Jair Rodrigues. Enquanto o termo "palhoça" remete-nos ao outro lado do Brasil, aquele que ainda era eminentemente rural, no qual habitações rústicas cobertas de palha ou colmo, típicas das áreas tropicais são componentes primordiais do cenário de então. As imagens criadas pelo refrão problematizam o lugar das novas tecnologias, simbolizada pela TV, em uma população, que na grande maioria, não tinha acesso a ela. Na continuidade da canção, novamente surge a imagem do monumento:

\section{O monumento é de papel crepom e prata \\ Os olhos verdes da mulata \\ A cabeleira esconde atrás da verde mata \\ O luar do sertão ((VELOSO in letras.mus.br)}

Mais uma vez, há um reforço do contraste através do termo monumento, que aqui aparece não somente como uma obra notável e duradoura evocada pela prata, mas também em sua constituição, elemento frágil e descartável como o papel crepom, remetemo-nos, mais uma vez a ideia "do mundo às avessas", o carnaval, que permite a qualquer um, experimentar, mesmo que por instantes a comunhão utópica de liberdade e fartura, de suspensão de todas as hierarquias e de dissolução da fronteira entre a arte e o mundo. Essas imagens estabelecem um diálogo bem interessante com obra que foi apresentada em Berlim 2002, pelo mexicano Eduardo Albaroa com sua escultura intitulada Portable broken obelisk (for outdoor markets), uma (re)leitura de uma obra estadunidense de Barnett Newman, Broken obelisk, que por sua vez já funcionava como uma (re)tomada de monumentais obeliscos que povoam as cidades pelo mundo afora desde a antiguidade. Tais instalações artísticas foram utilizadas como exemplo para as reflexões desenhadas por Jean Kluscinskas e Walter Moser em "A estética à prova da reciclagem cultural" (2017). Segundo os pesquisadores:

A "reciclagem" do obelisco comporta, entretanto, um trabalho maior de transformação: Newman não manteve o material natural de origem - o granito - mas produziu sua obra industrialmente em aço, por meio de uma empresa especializada. Passando de pedra ao aço, ele conservou um material nobre e durável, que está de acordo com as ideias tradicionais de monumentalidade e longevidade da obra de arte (vita brevis, ars lunga).

\section{$[\ldots]$}

Albaroa retomou a idéia e a montagem do Broken obelisk. Entretanto, mudou radicalmente de material. [...] Tratava-se, na realidade, de uma instalação artística móvel, [...] Inserindo o Broken obelisk na pobreza do México urbano e cotidiano, sua reciclagem estética abria um espaço de diálogo, potencialmente conflituoso, entre o Norte e o Sul.(KLUSCINKAS; MOSER, 2002, p.19) 
Lemos, pois, os monumentos de uma nação desconstruídos, passando do material durável e de grande resistência, para os frágeis, perecíveis, de papel fantasia, que põem em causa a própria ideia de nacionalidade. De que são constituídos, o que verdadeiramente representam? Uma ressignificação do que nos é ensinado na escola sobre a misturas de etnias que compõem o ser brasileiro. Literalmente o compositor se "alimentou" das informações oficiais e produziu algo bem paradoxal. Os verdadeiros monumentos, em nossa leitura, são os brasileiros, oriundos de misturas étnicas; os "olhos verdes da mulata", encerram a mistura da etnia europeia e da etnia negra. E a descendência indígena metonimicamente é referida no termo "cabeleira", palavra que designa os cabelos, sobretudo quando muito compridos. Como os cabelos das índias que foram cantadas por Alencar e Gonçalves Dias, e que se escondem "atrás das verdes matas" no interior do Brasil iluminados pelo "luar do sertão."

Pura antropofagia, canção devorando canção, para compor uma canção nova. Caetano devorou e parodiou o samba "Olhos Verdes" (1950), de Vicente Paiva, cantado por Dalva de Oliveira e a toada "Luar do Sertão" (1914), de Catulo da Paixão Cearense e João Pernambuco. 8

O monumento, uma alusão a capital no planalto central, Brasília, que, dessa vez, é carnavalizada e artificial, se contrapondo ao que será representado nos versos seguintes, nos quais encontramos um outro país, arcaicamente representado. Cidade planejada, ruas amplas em sintonia com a modernidade, o progresso, o desenvolvimento, enquanto ainda existe uma realidade crua de ruas de chão batido, tortas em um cenário antagônico que não está do lado de fora. O abismo não tem chave, não tem porta ele está lado a lado, naquele lugar a que chamamos país. Em sequência, a metáfora descreve um monumento, com outras características

\author{
O monumento não tem porta \\ A entrada é uma rua antiga estreita e torta \\ E no joelho uma criança sorridente feia e morta \\ Estende a mão
}

Continua a ideia de contraposições. A imagem é de fechamento, barreira, e o acesso ao monumento é impedido. O sociólogo português Boaventura de Sousa Santos em seu texto "Para além do pensamento abissal: das linhas Globais e uma ecologia de saberes." encontrado no livro Epistemologias do Sul (2010) afirma que:

As distinções invisíveis são estabelecidas através de linhas radicais que dividem a realidade social em dois universos distintos: o universo 'deste lado da linha' e o universo 'do outro lado da linha'. A divisão é tal que 'o outro lado da linha' desaparece enquanto realidade, tornase inexistente, e é o mesmo produzido como inexistente. Inexistência significa não existir sob qualquer forma de ser relevante ou compreensível. [...] A característica fundamental do pensamento abissal é a impossibilidade da co-presença dos dois lados da linha. (SANTOS, 2010, p.24)

\footnotetext{
${ }^{8}$ Há uma celeuma sobre a autoria da toada em questão. Esta composição está no rol das músicas que mais se identificam com a gente e a alma brasileira, do qual também fazem parte "Tristeza do jeca", "Aquarela do Brasil" e Asa branca". Tem letra de Catulo da Paixão Cearense, e há controvérsias quanto à melodia, oficialmente também creditada a Catulo, mas que teria sido elaborada pelo violonista João Pernambuco a partir do tema folclórico nordestino "É do Maitá". O que ninguém discute é a beleza e o sucesso irrestrito deste clássico da MPB. Foi lançado pela Odeon/Casa Edison em fevereiro de 1914, disco 120911.
} 
O momento econômico no qual a canção foi produzida alardeava aos "sete cantos" o conhecido "milagre econômico brasileiro", contudo é necessário frisar que era um milagre que literalmente dividia a nação e os brasileiros de forma abissal. De um lado os que existiam e recebiam benesses dessas medidas econômicas e de desenvolvimento e, de outro, os que definitivamente não existiam. Cada um em seu lado distinto. De um lado uma "rua antiga estreita e torta", enquanto do outro ruas monumentais, sem esquina, asfaltadas. Sendo a cultura brasileira tão complexa e híbrida a imagem de uma "criança sorridente feia e morta" estendendo a mão é a marca de uma sociedade que ocupa um lugar entre a riqueza e a miséria. Ao mesmo tempo em que são gastos milhões com a construção de uma nova capital federal não há preocupação com os miseráveis. O choque da estrofe é quebrado pelo refrão: "Viva a mata ta ta// Viva a mulata ta ta ta ta."

Viva, novamente, e um termo que permite leituras várias. Tal vocábulo pode ser percebido como uma interjeição que explicite uma felicitação, uma alegria, uma aprovação ou, até mesmo como expressão imperativa de um recôndito desejo de que nossas a matas sejam longevas, bem como sejam perpetuadas nossa mistura étnica e nossa identidade múltipla.

Viva a mata com sua exuberância e mistério. Viva a mulata tão representativa da miscigenação étnica do Brasil, embora hoje o termo não tenha a mesma força e esteja na lista das palavras "politicamente incorretas" devido à sua suposta origem ${ }^{9}$. Não se pode deixar de comentar a outra face da moeda com o corte das duas palavras, terminadas por ta-ta-ta, em uma reprodução fônica do som dos tiros, como sugerido quando se lê a mata como relativa ao verbo matar.

$\mathrm{Na}$ estrofe seguinte serão discutidas as questões que envolvem de forma mais incisiva a questão da desigualdade econômica existente no país:

\footnotetext{
No pátio interno há uma piscina

Com água azul de Amaralina

Coqueiros brisa e fala nordestina

E faróis ((VELOSO in letras.mus.br)
}

E o pensar no Brasil através de um levantamento e de um entrelaçamento de referências, continua. Tais imbricamentos permitem uma visão ampla dos dois lados opositivos da nação, de um lado a crescente burguesia representada por seus objetos de desejo e consumo como as piscinas, os carros metonimicamente representados pelos faróis, representações de um lado da linha invisível que separa o povo. As aspirações artificiais e modernas em contraponto às belezas naturais e arcaicas reforçam o distanciamento natural entre elas. Um olhar crítico sobre o antigo e o novo, uma reformulação geral na maneira de aproximar a modernidade e a tradição, componentes essenciais para se perceber o nacionalismo misturado que constitui

${ }_{9}^{9}$ A língua portuguesa foi buscar diretamente no latim mulus, no século XV, a palavra "mulo", ou seja, "animal híbrido, estéril, produto do cruzamento do cavalo com a jumenta, ou da égua com o jumento". No século seguinte, por influência do espanhol, o termo "mulato" era usado para designar um mulo jovem, e foi certamente por analogia com o caráter mestiço do animal que a palavra passou - a partir de meados do século XVI, segundo o Houaiss - a ser aplicada também, como adjetivo e substantivo, a pessoas descendentes de brancos e negros. O tom depreciativo da associação original é indiscutível e facilmente explicável pelo racismo escancarado de uma época escravocrata. 


\section{Roberta maria Ferbeira Alves}

1 OSEMESTRE DE $2020-$ N. 36

esse país. Os elementos da modernidade: "pátio interno", "piscina” e "faróis" se contrapõem aos elementos regionais: "coqueiro", "Amaralina", "fala nordestina", um interferindo no outro, modificando, reconstruindo, atualizando, uns indicando a tradição e os outros a modernidade.

Essa percepção polifônica prossegue acentuando as diferenças culturais, sociais e econômicas que constituem o país, unificadas pela figura do monumento, que nas palavras do compositor: "Brasília, a capital-monumento, o sonho mágico transformado em experimento moderno - e quase desde o princípio, o centro do poder abominável dos ditadores militares". Um monumento inaugurado no centro do país, de "papel crepom e prata", "sem porta" e "moderno". (VELOSO, 1997, p.185) A canção, através de imagens fragmentadas do passado e do presente, reestrutura um espaço imagético constituído de mundos antagônicos mantendo as contraposições:

Na mão direita tem uma roseira
Autenticando eterna primavera
E no jardim os urubus passeiam
A tarde inteira entre girassóis

(VELOSO in letras.mus.br)

Na sequência a pureza da infância é a porta de passagem que liga esses dois brasis e o contexto econômico e político no qual a canção foi composta. Uma cantiga de roda do folclore nacional é devorada e o verso, tão conhecido se transforma em carimbo de autenticação para uma eterna primavera, forçada, artificial e imposta, na qual aves de rapina, urubus (metonimicamente, representantes do lado obscuro do discurso do poder vigente que escondia as torturas, as prisões arbitrárias, o sufocamento dos movimentos estudantis camuflado no inconsciente coletivo pela ideia do paraíso tropical ) passeiam, diminuindo a beleza da liberdade, metaforicamente representadas pelos girassóis. Não há como não considerar aqui o momento político que o Brasil atravessava. Historicamente a direita é vinculada aos partidos políticos conservadores. Diante da ditadura civil e militar que vigorava desde 1964, podemos perceber o antagonismo entre a direita ditatorial que, através do verbo autenticar, linguagem utilizada nos cartórios para reconhecer a autenticidade de algum documento, decreta uma "eterna primavera". Um discurso que simulava um Brasil que atravessava um momento de paz, de desenvolvimento, sem conflitos. Contudo, mantendo os dois lados paradoxais da canção, sabemos que na mão direita tudo seguia a ordem estabelecida pelo simulacro ou escondido nos porões do silenciamento. Mais uma vez o ritmo é alterado pelo refrão, uma exaltação cinéfila e a amada terra do cancionista: "Viva Maria iá iá // Viva Bahia iá iá iá iá

Segundo o próprio Caetano em seu livro Verdade Tropical, Viva Maria faz referência a um filme homônimo de Louis Malle estrelado por Brigitte Bardot. ${ }^{10} \mathrm{~A}$ atriz materializa a influência do cinema na cultura brasileira em um diálogo possível com a cultura estrangeira. Além disso,

\footnotetext{
${ }^{10}$ Filmado em sua maioria em locações no México, o filme conta a história de Maria II (Bardot), a filha de um terrorista irlandês que acabou de perder o pai, que se encontra com Maria I (Moreau), uma cantora de circo, no interior de um país imaginário da América Latina, em 1907. Maria II resolve fazer parte do circo com Maria I e quando as duas fazem um número de canto, elas acidentalmente inventam o strip-tease, o que torna o circo famoso. Durante suas aventuras com o circo, acidentalmente elas conhecem um líder revolucionário (Hamilton) socialista e as duas acabam se tornando líderes de uma revolução contra o ditador local, a igreja e o capitalismo.
} 
o personagem por ela representado no filme se configura como uma possível materialização dos desejos revolucionários abrigados na alma do baiano de Santo Amaro da Purificação.

A Bahia, terra de Caetano, também é exaltada nesse trecho; da mesma forma que o verso anterior, a rima é mantida na repetição do ditongo crescente "iá iá". Podemos dessa forma ver um diálogo antropofágico na utilização de uma marca popular de fala, herdada da forma pela qual os escravos negros se dirigiam às suas senhoras ou qualquer mulher branca que lhes fosse superior, já que iá é mãe na língua iorubá (VELOSO,1997. p. 187);

Mais uma vez, caminhos antagônicos da mesma estrada. Uma mistura possível embora tão antagônica. Se na mão direita tem uma roseira o que carrega a esquerda?

\author{
No pulso esquerdo um bang-bang \\ Em suas veias corre \\ Muito pouco sangue \\ Mas seu coração \\ Balança a um samba de tamborim
}

(VELOSO in letras.mus.br)

A esquerda estava na guerrilha, imagem suscitada pela onomatopeia bang-bang, registro típico de filmes hollywoodianos americanos muito apreciados no período é mais uma referência ao cinema. Retomando um trecho da estrofe anterior que afirma estar "na mão direita" uma roseira, autenticando a coexistência de uma eterna primavera na qual, alegoricamente (referência a outra cantiga de roda), "urubus passeiam a tarde inteira entre os girassóis". E em uma conexão direta com os dois campos estabelecidos nos versos que dão continuidade à canção, percebemos uma completude apartada através das diferenças, lados diferentes que completam e deslocam a ideia do todo. Enquanto temos uma roseira de um lado, do outro temos a arma. Concepções díspares que formam um corpo/nação.

Em contrapartida, diante de tanta luta, há uma coisa que traz um pouco de alegria ao coração: o samba, o ritmo eminentemente e dito genuinamente brasileiro, nele e através dele as energias eram recompostas. E nesse momento a canção,

\author{
Emite acordes dissonantes \\ Pelos cinco mil auto-falantes \\ Senhoras e senhores \\ Ele põe os olhos grandes \\ Sobre mim
}

(VELOSO in letras.mus.br)

O canto vai explicitar nessa estrofe uma homenagem a um dos grandes ídolos de Caetano Veloso. Falamos de João Gilberto que, ao lançar mão de acordes dissonantes, inaugura a Bossa Nova; um novo jeito de tocar violão e cantar que rejuvenesce a música brasileira ao experimentar novas possibilidades estéticas e é através dos "cinco mil alto-falantes" que essa canção manifesto é propagada. Embora nada disso aconteça sem haver um distanciamento do 
momento crítico de censura e controle pelo qual a cultura brasileira passava tais olhos grandes que, mencionados trazem novamente à tona a situação política em que, num clima repressor, todos eram vigiados.

Mais uma vez temos um refrão de letra variável que propõe uma análise sincrônica e diacrônica ao ligar duas musas separadas no espaço-tempo: "Viva Iracema ma ma// Viva Ipanema ma ma ma ma."

A índia do romance de José de Alencar e a garota de Ipanema cantada por Tom Jobim e Vinícius de Moraes são colocadas lado a lado produzindo uma reflexão interessante, reciclando e ressignificando Iracema que sai das páginas do romance oitocentista e repousa como homenagem à heroína nacional como nome dado a uma praia no Ceará e Ipanema, nome de uma praia no Rio de Janeiro que foi tomado de empréstimo para homenagear uma garota (VELOSO, p. 187). Ao aproximar essas duas personagens e essas duas praias tão distantes no espaço-tempo, torna pequena a distância que separa as duas regiões do Brasil ao mesmo tempo em que demonstra a multiplicidade das identidades culturais do país.

Em seguida a canção retoma seu universo musical, falando de elementos do cancioneiro nacional; o tema musical é reintegrado bem como o espaço no qual ele é concebido.

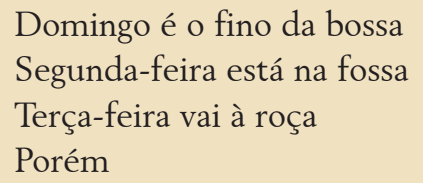

(VELOSO in letras.mus.br)

Uma informação repleta de aproximações com as crônicas históricas. Nesse trecho da canção, o compositor data suas informações, pois simplesmente cita o que na época fazia parte daquele lado moderno e desenvolvido da população que, de uma forma ou de outra, tinha acesso à programação da televisão e acompanhava o programa de Elis Regina e Jair Rodrigues, "O fino da bossa". Nas palavras do compositor em seu livro a fossa de segunda feira alude tanto ao programa "O Fino da Bossa" dedicado ao samba quanto ao Solar da Fossa, codinome do apartamento no qual Caetano morou. Além desses significados conexos com o mundo do compositor, podemos estabelecer novas vinculações para o termo fossa, que também permitem uma leitura contextualizada a partir de seu significado como substantivo feminino. Dessa maneira, ao entendermos fossa como uma cavidade mais ou menos larga e profunda no solo; cova, fosso, ou ainda perceber seu significado negativo enquanto gíria, designando o estado de quem está muito triste, deprimido, sem disposição para enfrentar a situação, fica demarcado o momento vivido no qual a situação é delineada como um momento de ausência de esperança de mudança gerando um desânimo e uma inércia total.

A vida continua em uma sequência lógica padrão, através da colocação dos dias da semana, em ordem cronológica: temos no domingo a alegria simulada em um programa de tv, na segunda a realidade volta a ser experienciada, e finalmente na terça, mais uma vez, os espaços são contrapostos através de uma mudança espacial. Como se o sujeito lírico se deslocasse de um 


\title{
Roberta maria Ferbeira Alves
}

1 OSEMESTRE DE $2020-N .36$

centro urbano, desenvolvido para um outro local não tão desenvolvido, reafirmando assim a tênue linha que divide os dois espaços nacionais. O verso é na terça que se vai a "roça", nos permite inferir, mais uma vez a diferença abissal existente na constituição desse país: de um lado o moderno dado como desenvolvido e do outro o rural, não desenvolvido. Apesar de ter delineado essa diversidade, o sujeito lírico finaliza a estrofe com uma conjunção adversativa introduzindo os próximos versos de forma opositiva, ao que acaba de afirmar. A despeito dessa diferença toda, o que importa a determinados olhares é que

\author{
O monumento é bem moderno \\ Não disse nada do modelo do meu terno \\ Que tudo mais vá pro inferno \\ Meu bem \\ Que tudo mais vá pro inferno \\ Meu bem
}

(VELOSO in letras.mus.br)

O monumento reaparece moderno e ofuscando a visão para outros acontecimentos e fatos que porventura existam nesse momento. Segundo Caetano, "Brasília sem ser nomeada, seria o centro da canção, monumento aberrante que eu ergueria à nossa dor, à nossa delícia e ao nosso ridículo." (VELOSO, 1997, p. 185) Nessa estrofe final o diálogo se estabelece entre os $2^{\circ}$ e $3^{\circ}$ versos do trecho analisado e versos de canções do repertório do cantor e compositor Roberto Carlos em parceria com Erasmo Carlos, e a representatividade de suas canções, no cenário nacional de então. Em um primeiro momento, o poeta baiano, faz alusão a canção "Os mexericos da Candinha" (1965), composição com contornos de uma crônica, cujos versos apresentam o personagem Candinha, como era conhecida a maior fofoqueira da TV e do rádio brasileiros dos anos 1960. Tal personagem, reinava absoluta do alto de sua caricatura de óculos gatinho na "Revista do Rádio" na conhecida coluna, "Mexericos da Candinha". Semanalmente a coluna estava repleta de insinuações, nas quais cabia ao público adivinhar quem era quem, da mesma maneira em que se colocava medo de terem revelados os segredos daqueles que se comportavam mal. Atrás dos seus óculos "gatinho", havia olhos que viam tudo. A mexeriqueira na estrofe dos compositores da jovem guarda aparece assim: "A Candinha quer fazer da minha vida um inferno/ Já está falando do modelo do meu terno[...]." Cumprindo seu papel de bisbilhoteira, o personagem fala mal do jeito de se vestir do sujeito lírico além de outras atitudes comportamentais da juventude. Ao ressignificar em sua canção o verso, Caetano se coloca em um lado oposto ao do sujeito lírico da canção de Roberto e Erasmo Carlos. O sujeito lírico de "Tropicália", simplesmente não é alvo dessas maledicências e ainda subverte o termo "inferno" estabelecendo um diálogo com outra canção do cancioneiro do compositor capixaba.

Na canção de Roberto Carlos, "Quero que vá tudo pro inferno" (1965), que também faz parte do álbum Jovem Guarda, encontramos o outro ponto de aproximação estabelecido pela canção de Caetano. Nos versos da canção fonte temos, em um clima romântico de amor, de saudade: "Não suporto mais, você longe de mim/Quero até morrer, do que viver assim/Só quero que você, me aqueça neste inverno/ E que tudo mais vá pro inferno". Visivelmente, o sujeito lírico sofre de saudade, e coloca seu amor acima de tudo que existe. O inferno, dessa 


\section{Roberta maria Ferbeira Alves}

1 O SEMESTRE DE $2020-$ N. 36

vez ressignificado, assume a posição de uma imprecação, uma maneira de exorcizar demônios, valores e amarras, e não mais se refere, ao constrangimento, ou perturbação causados pela fofoqueira.

Esse monumento está inserido em um contexto diferenciado, dividido com o programa chamado "Jovem Guarda", liderado por Roberto Carlos. Sabemos que esses dois movimentos aparentemente representavam os dois lados da música brasileira da época; enquanto o Tropicalismo era ligado às questões sociais, a Jovem Guarda não era totalmente aceita por grupos que os considerava como alienados. Contudo, dentro da Tropicália eles encontram espaço, uma vez que também integram o que se concebe como música popular brasileira, dado o seu enorme sucesso junto ao público. Embora o estilo hippie e os cabelos desalinhados de um grupo e o arrumadinho e os cabelos lisos e comportados do outro aparentemente os colocasse em mundos antagônicos, não podemos esquecer que, afinal, essa era a proposta do Tropicalismo, alimentar-se de toda forma e expressão de cultura para poder produzir que pudesse ter características de uma arte mais universal.

O último refrão encerra reverenciando o meio pelo qual toda essa discussão é possível: "Viva a banda da da// Carmem Miranda da da da da// Viva a banda da da// Carmem Miranda da da da da".

"A banda" é o nome de uma das mais famosas canções de Chico Buarque, vencedora do Festival de Música Popular Brasileira (FMPB) de 1966. A canção, aparentemente inocente, nos apresenta uma cidadezinha triste que ao ser atravessada por uma banda ganha vida e ânimo, ou pelo menos assim seus habitantes se comportam. Em uma outra leitura, também plausível, a canção mostra como a vida sai do eixo quando algum acontecimento aparentemente festivo acontece, falsas ilusões, esperanças quebradas, sonhos desconstruídos, mas em clima de euforia muitas coisas passam, desapercebidas.

Na primeira leitura, podemos sentir que a presença da música desempenha o papel de metáfora, uma vez que o povo muitas vezes só conta com a banda para ter um pouco de alegria. Carmem Miranda, embora portuguesa, foi uma estrela do show business brasileiro e americano. Em suas apresentações havia sempre tentativas de resgate do que seria algo mais brasileiro, estereótipos da cultura nacional: a baiana, os grupos de samba, a figura do bom malandro, imagens que ainda permanecem no imaginário de estrangeiros que não conhecem o Brasil. Nas palavras de Caetano, "Carmem Miranda emblema tropicalista, um signo sobrecarregado de afetos contraditórios”. (VELOSO, 1997, p. 267-268). Cremos que, ao colocá-la no último refrão da música, faz explicitamente uma sugestão de que a cultura brasileira não só sofre influências externas mas também influenciaria outras culturas, tendo em vista o enorme sucesso que ela alcançou nos E.U.A na década de 40, vindo a tornar-se a artista mais bem paga de Hollywood em 1946, uma materialização da cultura brasileira tipo exportação.

A influência moderna se faz perceber ao longo de toda letra, nas imagens surrealistas, as máquinas futuristas e na rima que repete a última sílaba no último refrão, uma alusão ao movimento Dadaísta ou Dadá que propunha uma radical negação de todos os valores. E um tanto de outras inferências internas como os nomes de Dadá, esposa do cangaceiro Corisco, e 


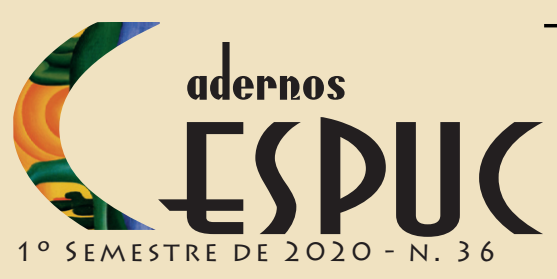

\section{Roberta maria Ferbeira Alves}

do famoso jogador de futebol Dadá Maravilha, uma refeição completa, segundo declarações do compositor.

Que essa canção, “Tropicália” não seja simplesmente vista como inventário das identidades culturais brasileiras. E sim como um banquete antropofágico que, através de paródias, alusões, contrastes, contradições, trata do panorama cultural, histórico, social de épocas distintas.

O jogo especular provocado por essas estratégias discursivas que abrem um diálogo entre vozes nas quais contrapõem-se a política desenvolvimentista de Juscelino Kubistchek e Brasil rural, o brega e a vanguarda, o artesanal e o urbano industrial. Esse jogo de espelhos, como naquelas atrações circenses que transitavam e transitam pelo interior do país, permite que referências aparentemente díspares suscitem novos sentidos, denotando a complexidade que envolve a constituição de uma identidade cultural brasileira. A letra da canção apresenta uma sucessão de representações expostas contraditoriamente, nas quais existem críticas ao quadro histórico e social do país intercaladas a valorizações de elementos brasileiros. Uma canção que valoriza a beleza reluzente deste grandioso Estado brasileiro, mas que pode ter partes feitas de uma liga de papel e cola. A poesia é um contraponto que estabelece paradoxos entre crítica e o elogio à beleza e modernidade.

O monumento sem porta da letra é o Brasil, que tem diante de si um antigo caminho, com antigos problemas e antigas estruturas oligárquicas; é a contradição pungente entre o desenvolvimento e a criança feia e morta que insiste em estender a mão. A Tropicália assume o Brasil em sua face bela e repulsiva, expõe a imagem chocante da desigualdade social, na proximidade que existe entre a riqueza dos grandes centros, e a pobreza, que se mostra no sertão nordestino e nos altos índices de mortalidade infantil.

A justaposição de elementos diversos sem estabelecer uma relação hierárquica cujos determinados símbolos aparecem numa posição de superioridade com relação a outros, dialoga com a proposta da pós-modernidade em repensar a constituição da identidade nacional. Ao contemplar as peculiaridades que envolvem aquilo que se concebe como cultura brasileira, a canção lida com um imaginário cultural fragmentado polifônico, na qual retumbam vozes silenciadas no processo de construção da identidade nacional. Os vários aspectos híbridos da cultura, da sociedade e da história convivem na tensão.

Impossível esquecer que o Brasil foi um país colonizado por Portugal, que aqui já se encontravam os índios, que depois chegaram os negros, posteriormente os imigrantes de várias partes do mundo e isso implica em considerar os diversos discursos de uma cultura que tem uma formação tão heterogênea. Caetano afirma em suas crenças, atitudes e palavras que:

Sempre cri numa espécie de organicidade da assimilação de informações, e faço questão de tratar com naturalidade a acumulação de cultura, retendo dos livros, das aulas, das canções somente o que me for congenial, e transmitindo somente o que já estiver por mim incorporado. (VELOSO, 1997, p.279)

Assim podemos afirmar que, antropofagicamente, ele conseguiu devorar e digerir em acordes dissonantes o legado do paulistano antropófago indigesto em seu movimento musical 


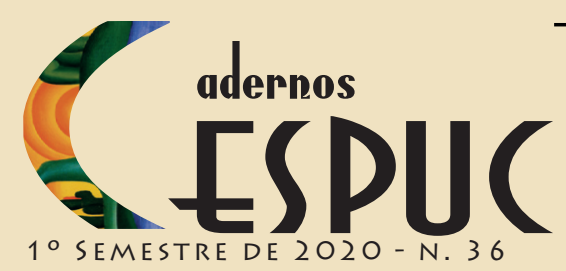

\section{Roberta maria Ferbeiba flves}

e na canção manifesto, Tropicália, uma tragicomédia em que há lugar para alegria, miséria, opressão, musicalidade, sonho na complexa singularidade do que é ser brasileiro. Uma canção que desenha um painel de grandeza épica de um povo em formação apresentado com grandes doses de crueldade, de desigualdade sem se esquecer da exuberância, da alegria, da força e da energia da resistência. Um retrato que nos convida a olhar os variados problemas nacionais sem cair nas amarras da tristeza. O tom dissonante escolhido é de um pessimismo alegre que nos permite ver o local escuro no qual estamos mantendo um tom trágico e colorido da alegria. 
Referências

ABBEVILLE, C. d'. História da missão dos padres capuchinhos na Ilha do Maranhão e terras circunvizinhas. tradução de de S. Milliet, São Paulo, Edusp. 1975

AGNOLIN, Adone. Antropofagia ritual e identidade cultural entre os Tupinambá. Rev. Antropol. São Paulo, v. 45, n. 1, p. 131-185, 2002. Available from <http://www.scielo. br/scielo.php?script =sci_arttext\&pid $=$ S0034-77012002000100005\&lng $=$ en\&nrm $=$ iso $>$. access on 23Apr. 2020. https://doi.org/10.1590/S0034-77012002000100005.

ALENCAR, José de. Iracema, lenda do Ceará. São Paulo: Ática, 1987.

ANDRADE, Oswald. Manifesto Antropófago. A utopia antropofágica. São Paulo: Globo, 1990.

ANDRADE, Oswald. Pau-Brasil. São Paulo: Globo, 1990.

BAKHTIN, M. A cultura popular na Idade Média e no Renascimento: o contexto de François Rabelais. São Paulo: Hucitec, 1999.

COSTA LIMA, Luis. "Antropofagia e controle do imaginário"; "Bernardo Guimarães e o cânone". In: COSTA LIMA, Luis. Pensando nos trópicos (dispersa demanda II). Rio de Janeiro: Rocco, 1991.

COSTA LIMA, Luis. Permanência e mudança na poesia de Mário de Andrade. In: COSTA LIMA, Luis. Lira e antilira. Rio de Janeiro: Topbooks, 1995.

DUARTE, Paulo Sérgio. Hélio Oiticica: a Tropicália além da forma. In: DUARTE, Paulo Sérgio; NAVES, Santuza Cambraia (org.). Do samba-canção à Tropicália. Rio de Janeiro: RelumeDumará: Faperj, 2003.

FAVARETTO, Celso. A Invenção de Hélio Oiticica. São Paulo: Edusp, 1992. (Texto \& arte, 6).

FAVARETTO, Celso. Tropicália, alegoria, alegria. 3.ed. São Paulo: Ateliê, 2000

FERNANDES, F. A função social da guerra na sociedade tupinambá. São Paulo, Livraria Pioneira 1989

FLORESTAN, F. A organização social dos tupinambá, São Paulo, Huicitec/UnB,1989

KLUCINSKAS, J., \& MOSER, W. (2017). "A estética à prova da reciclagem cultural". Scripta, 11(20), 17-42. Disponível em; < http://periodicos.pucminas.br/index. php/scripta/article/view/14019> Acesso em 22 Jan. 2020.

MONTEIRO, A. "Romantismo e Modernismo: A Construção Do Cânone de nacionalidade da literatura brasileira. Revista Verbo de Minas. Juiz de Fora v.8, n.15. Jan./Jun. 2009. p. 211 223.

NUNES, Benedito. "A Antropofagia ao Alcance de Todos" (Introdução) In: Obras Completas 


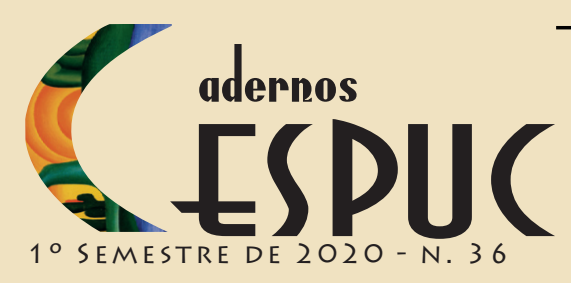

\section{Roberta maria Ferbeira Alves}

de Oswald de Andrade, vol. VI, Do Pau-Brasil à Antropofagia e às Utopias. 2a ed., Rio de Janeiro, Civilização Brasileira, 1970.

SANTIAGO, Silviano. Oswald de Andrade ou: Elogio da tolerância étnica. In: 2 Congresso Abralic: Literatura e memória cultural. Anais. vol. 1. Belo Horizonte: Abralic, 1991.

SANTIAGO, Silviano. A permanência do discurso da tradição no modernismo. In: SANTIAGO, Silviano Nas malhas da letra. Rio de Janeiro: Rocco, 2002.

SANTOS, Boaventura de Sousa. "Para além do pensamento abissal: das linhas Globais e uma ecologia de saberes." In: SANTOS E MENESES (org.). Epistemologias do Sul. São Paulo: Côrtez. 2010. p. 23-71

SILVA K. H. S.; AZEVEDO, T de. Tropicália e a pós-modernidade: uma (re) leitura possível. Disponível em: <http://www.ciencialit.letras.ufrj.br/garrafa/garrafa20/ karinhallanaetaniadeazevedo_tropicaliaeapos.pdf > . Acesso em 20 Fev. 2020.SOUZA, Roberto Acízelo. Introdução à historiografia da literatura brasileira. Rio de Janeiro: EdUERJ, 2007.

STADEN, H. Duas viagens ao Brasil. São Paulo, Edusp.1974

TROPICÁLIA. Disponível em: < http://tropicalia.com.br/identifisignificados/movimento $>$. Acesso em: Fev. 2020.

TROPICÁLIA. Disponível em: <http://enciclopedia.itaucultural.org.br/termo3741/ tropicalia >. Acesso em: Mar. 2020.

VELOSO, Caetano. Verdade tropical. São Paulo: Cia das Letras, 1997.

VELOSO, C.; COSTA ,G.; GIL, G.; LEÃO, N.; OS MUTANTES; TOM ZÉ; CAPINAM; TORQUATO NETO; DUPRAT, R. Tropicália ou Panes at circenses. Edição histórica. Rio de Janeiro: POLIGRAN, 1982. Série Verde. Stereo. 